\title{
Bidragsyterne - Contributors
}

Tsjalling Swierstra, PhD

Professor of Philosophy, Maastricht University, The Netherlands

Email: t.swierstra@maastrichtuniversity.nl

Research area: the ethics and politics of emerging technologies

Rune Nydal, Dr. art

Associate Professor, Programme for Applied Ethics, Department of Philosophy \& Religious Studies

NTNU, Trondheim

Email: rune.nydal@ntnu.no

Research area: Ethics of science and technology, research ethics, Philosophy of science/STS,

Integration of ethics in large science programs.

Lisbeth Højbjerg Kappelgaard, Cand. mag.

Ph.d. stipendiat og Studieadjunkt, Aalborg Universitet, Danmark

E-post: lisbethhk@hum.aau.dk

Forskningsområde: humanistisk sundhedsforskning, etik og selvmonitorering

Erik Thorstensen, MA

Senior Researcher, Oslo and Akershus University College of Applied Sciences (HiOA)

Email: Erik.Thorstensen@afi.hioa.no

Research area: technology assessment, responsible innovation, ethics, climate change

Peter Danielson, $\mathrm{PhD}$

Mary \& Maurice Young Professor of Applied Ethics, Centre for Applied Ethics, School of Population \& Public Health, University of British Columbia, Canada

Email: danielsn@exchange.ubc.ca

Research area: computational (agent-based, evolutionary) modelling of ethical agents, constructing computational spaces to support democratic decision making in ethics, experimental public participation evaluations of technologies

Allen Alvarez, PhD

Researcher, Programme for Applied Ethics, Department of Philosophy \& Religious Studies NTNU, Trondheim

Email: allen.alvarez@ntnu.no

Research area: rationing healthcare in extreme scarcity, basic needs and moral agency, ethics of enhancement technologies, experimental public participation evaluations of technologies, multicultural deliberation ethics, empirical methods in bioethics

Lumberto Mendoza, MA

Assistant Professor in Philosophy, University of the Philippines Diliman

Email: lumberto.mendoza@up.edu.ph

Research area: Wittgensteinian ethics, Kantian Ethics, social and political philosophy, feminist ethics, philosophy for children, experimental public participation evaluations of technologies.

Ole Martin Moen, $\mathrm{PhD}$

Postdoctoral Fellow in Philosophy, Centre for the Study of Mind in Nature, University of Oslo

Email: o.m.moen@ifikk.uio.no

Research area: ethics, especially thorny issues in applied ethics that have traditionally received little attention from philosophers 